\title{
Are Kuwaiti Stock Returns Affected by Fluctuations in Oil Prices?
}

\author{
Salem Alshihab ${ }^{1} \&$ Nayef AlShammari ${ }^{2}$ \\ ${ }^{1}$ Senior Financial Analyst, Kuwait National Assembly, Kuwait \\ ${ }^{2}$ Economics Department, College of Business Administration, Kuwait University, Kuwait \\ Correspondence: Nayef AlShammari, Associate Professor, Economics Department, College of Business \\ Administration, Kuwait University, Kuwait. E-mail: alshammari@cba.edu.kw \\ Received: July 30, 2020 \\ doi:10.5430/ijfr.v11n6p1 \\ Accepted: September 1, $2020 \quad$ Online Published: November 30, 2020 \\ URL: https://doi.org/10.5430/ijfr.v11n6p1
}

\begin{abstract}
This paper examines the impact of fluctuations in the price of oil on Kuwaiti stock market returns for the month-to-month period of 2000 to 2020. The Augmented Dickey-Fuller (ADF) test for stationarity, the error correction model (ECM), and various cointegration test techniques were used to examine the estimated model. In an oil-based economy like Kuwait, the exposure to oil prices seems to affect the performance of the country's stock market. Our main findings related to the long run showed that the price of oil is cointegrated with stock market returns. Interestingly, our ECM examination confirmed that changes in Kuwaiti stock market returns are only affected by oil price fluctuations in the short run. Further strategies are needed to better stabilize Kuwait's capital market. This equilibrium can be achieved by pursuing more stability in other macroeconomic factors and providing a solid legal independence for the country's financial market.
\end{abstract}

Keywords: oil price, macroeconomics, stock market, Kuwait

JEL Classification Codes: Q41, E02, G1, N95

\section{Introduction}

The volatility of oil prices is of considerable concern to oil-exporting countries because these economies have high exposure to such fluctuations. Crude oil prices not only impact the channels of oil revenue but also affect other markets and institutions in the economies of oil-exporting countries. One of these markets is the stock market which has received increased attention from researchers.

Investigating the impact of oil prices on the capital market requires looking at different variables affecting the market with one critical factor being macroeconomics. The relationship between macroeconomic variables and stock market returns differs from one country and time to another due to many factors. Such factors include capital mobility regulations (Lin et al., 2010), the status of oil net exports/imports (Antonakakis \& Filis, 2013), and the period of observation and timing of the impact (Celebi \& Hönig, 2019). Macroeconomic factors include, but are not limited to oil prices, interest rates, exchange rates, the money supply (M2), and the consumer price index (CPI). Other factors, such as foreign direct investment (Soumaré \& Tchana, 2015) and capital expenditures (Burton, 2005; Akbar et al., 2008), were not considered in this study due to a lack of data.

This study investigated the impact of oil prices fluctuations on the returns of the Kuwaiti stock market by studying the relationship of macroeconomic factors to the aggregate market returns in the country. The data sample covered the period from June 2000 to January 2020 at a monthly basis. The study employed different examination tools such as the augmented Dickey-Fuller (ADF) test for stationarity, the error correction model (ECM), and cointegration tests.

Our findings revealed that there was a long-term relationship between macroeconomic factors and Kuwaiti stock market returns. Particular evidence confirmed that oil prices were cointegrated with stock market returns in the long run. However, short-term findings revealed that changes in stock market returns were only affected by changes in the price of oil. In contrast, the long-run ECM showed evidence that market returns were affected positively by both changes in interest rates and the money supply; however, the impact on the Consumer Price Index (CPI) was negative.

The rest of this paper is organized in the following sections: Section II. Literature Review; Section III. Model Specification; Section IV. Data and Descriptive Analyses; Section V. Results; and finally, Section VI. Conclusion and Policy Implications. 


\section{Literature Review}

Many studies have investigated the interaction between macroeconomic variables and stock market returns, for example, the research completed by King (1966), Almutairi \& Alomar (2007), González, Nave, \& Rubio (2018), and Aldukhail (2019). King (1966), specifically, using factor analysis, suggested that 50 percent of stock market returns can be explained by macroeconomic factors. Macroeconomic factors include, but are not limited to interest rates, exchange rates, oil prices, and the money supply. A recent study conducted about firms in the Gulf Cooperation Council (GCC), which used three parameters (exchange rates, interest rates, and oil prices) to investigate their relationship to stock returns, suggested that the results vary from one industry to another (Alenezi et al., 2020). In Kuwait, financial firms were less exposed to fluctuations in exchange and interest rates than nonfinancial firms. Of the three parameters, the study found that exchange rates impacted the Kuwaiti stock market the most. The effects of the two others, interest rates and oil prices, will be investigated in later sections of this paper.

For the period 1987-2014, Sahin (2014) investigated the impact of interest rates, income growth, the money supply, exchange rates, and oil prices on the returns of the Istanbul Stock Exchange (Borsa Istanbul). He found that oil prices had a negative impact on returns in Turkey because the country is an oil importer. Increases in oil prices caused higher production costs. Sahin also found that rising exchange rates had a negative impact on stock returns because such rates increase the cost of production.

In a 2016 study, Ahmadi et al. studied the impact of global oil market on U.S. stock returns during the period 19732013. They found that the impact of fluctuations in oil price depended on the causes behind the shock. A speculative demand for oil was found to be the only cause for lowering stock aggregate returns, while supply shocks did not have a significant impact on stock market returns. For the period 1989-2007, Jammazi (2012) investigated stock return-oil price interactions in five developed countries: The United States, The United Kingdom (UK), Germany, Japan, and Canada. The empirical results of the study showed that in all five countries (except for the UK) crude oil prices had a significant long-term impact on stock market returns, while short-run impacts were found to be minimal.

Interest rates are one of factors that are often found to have a major impact on stock market returns. Most studies found empirical evidence proving a negative relationship between interest rates and stock market returns. Amarasinghe (2015) studied the impact of interest rates on the All Share Price Index of the Colombo Stock Exchange. The findings were compatible with the other literature - there was a negative relationship between interest rates and stock market returns. In 2017, Fang and Bessler attempted to see whether interest rates could help predict the market returns of the Shanghai Stock Exchange Composite Index. Their study found that interest rates can help forecast stock returns with statistically significant outcomes.

Using quarterly data for the period 1952-2015, Pícha (2017) studied the impact of deposits and currency and value of equities and treasury in U.S. household portfolios on the performance of the S\&P 500. The variable deposits and currency represent the money supply in the study. The study found that, in the long term, the three variables have a positive relationship with stock returns because an increase in any variable results in an increase in the index. As for the short term, Pícha (2017) found that money supply had the highest speed of adjustment when compared with the other two independent variables. During the observed order of lag (6 months), stock returns were heavily affected by changes in M2.

\section{Model Specification}

Investigating the influence of oil prices on stock markets can be traced to different theoretical backgrounds. The equity theory is used to analyze such a relationship (i.e., Arouri et al., 2012). According to this theory, an increase in oil price tends to affect the production of inputs which leads to higher inflation levels. This eventually may cause a reduction in expected stock market earnings for investors (i.e., Al-Fayoumi, 2009; Arouri \& Nguyen, 2010). The other theory is information theory (i.e., Green \& Mork, 1991; Mensi et al., 2012; and An et al., 2018) which assumes the efficiency in the market ensures efficient asset prices.

The influence of oil prices on stock market returns has been investigated through linkages within different contexts of macroeconomic variables. This type of analysis was initiated by the symmetric theory of Hamilton (1983). Such a theoretical framework has evidence from empirical work (i.e., Burbidge \& Harrison, 1984; Gisser \& Goodwin, 1986; and Kelikume \& Muritala, 2019). Accordingly, this study used the symmetric theory to investigate the relationship between oil prices and stock market returns in Kuwait.

The mean reverting nature of the examined sample is tested through the ADF test for stationarity (Cheung \& Lai, 1995). It is an extension of the original Dickey-Fuller test (1979). The test is implemented under the null hypothesis that the variable contains a unit root, and the alternative hypothesis that the variable is generated by a stationary process. The ADF test estimates a linear model with a least squares estimator where the first difference of the time 
series at time $t$ is regressed on the level at time $t$-1, augmented with lag terms of the dependent variable. Then, the stationarity is checked based on the significance of the level term.

$$
\Delta X_{t}=\alpha_{0}+\rho X_{t-1}+\delta T+\sum_{i=1}^{P} \alpha_{i} \Delta X_{t-i}+\varepsilon_{t}
$$

Where $X_{t-1}$ and $\Delta X_{t}$ are the level and the first difference of the tested variable at time (t-1) and $(t), T$ is a time trend, $\sum_{i=1}^{P} \alpha_{i} \Delta X_{t-i}$ are corresponding lag terms up to order $P$, and $\varepsilon_{t}$ is the error term. $\rho$ is the coefficient of interest and testing the hypothesis $\rho=0$, is equivalent to testing that $X_{t}$ follows a unit root process. In the ADF test, the optimal lag order was chosen based on Akaike and Bayesian information criteria (AIC, BIC); different models were estimated with inclusion of lag terms up to a maximum lag order, then the best model was chosen as the one with the minimum values of AIC and BIC criteria.

The cointegration test was applied next. The examined variables follow I(1) processes. The estimated model is tested to determine if variables are cointegrated, meaning whether they follow a long-run equilibrium. The test is implemented through Johansen trace statistic and maximum eigenvalue statistic methods. The null hypothesis of the both tests is that there are no more than $r$ cointegrating vectors. The distribution of the trace statistic is given by:

$$
\lambda_{\text {trace }}(r)=-T \sum_{i=r+1}^{n} \ln \left(1-\widehat{\lambda_{l}}\right)
$$

Where $T$ is the number of used observations, $r$ is the number of cointegrated vectors, and $\widehat{\lambda_{l}}$ is the estimated value of $i$ th eigenvalue. The test statistics follow $\chi^{2}$ distribution. It is important to note that the appropriate number of lags in the test specification can be chosen based on the lag order selection criteria from an initial VAR estimations.

The ECM is used for further investigation. In the ECM, the short-run dynamics of the variables in the system are influenced by the deviation from long-run equilibrium. The ECM specifications can be presented as

$$
\Delta y_{t}=\alpha\left(y_{t-1}-\theta^{\prime} X_{t}\right)+\sum_{j=1}^{p} \rho_{j} \Delta y_{t-j}+\sum_{j=1}^{p} \beta_{j}^{\prime} \Delta X_{t-j}+\epsilon_{t}
$$

Where $\alpha$ is the error-correcting speed of the adjustment term and is expected to have significant negative impact (otherwise there would be no evidence for a long-run relationship), $\theta$ are parameters of long-run relationships between the variables, and $\rho_{j}$ and $\beta_{j}^{\prime}$ are short-run effects.

\section{Data and Descriptive Analyses}

As summarized in Table (1), the historical interest rates, exchange rates, and money supply figures were obtained from Central Bank of Kuwait. Historical oil prices were obtained from the World Bank database. Index prices and CPI data were obtained from the Kuwait Stock Exchange and the Kuwait Central Statistical Bureau, respectively. The observation period was monthly from June 2000 to January 2020, resulting in a total of 220 observations.

Table 1. Variable descriptions

\begin{tabular}{llll}
\hline$E q$ & Kuwaiti index & $g E q$ & Kuwaiti index returns \\
Oil & Oil prices (end of month) & $g O i l$ & Oil price returns \\
Int & Interest rate & $g I n t$ & Interest rate growth \\
$M 2$ & Money supply (USD millions) & $g M 2$ & Money supply growth \\
$E x$ & Exchange rate for KD vs. USD & $g E x$ & Exchange rate growth \\
$C P I$ & Consumer Price Index & $g C P I$ & CPI inflation \\
\hline
\end{tabular}


The variable descriptions are presented in Table 1. The main descriptive statistics are given in Table 2. For the examined period, the average equity market return was about $0.67 \%$ (with a minimum of $-32.37 \%$ and a maximum of $18.44 \%$ ). The average money supply growth rate was about $0.67 \%$ (with a minimum of $-4.83 \%$ and a maximum of $7.93 \%$ ). The average interest rate was $3.61 \%$ (with a minimum of $2 \%$ and a maximum of $7.25 \%$ ). The average oil price was about USD 63.54 (with a minimum of 18.52 and a maximum of 132.83). On average, the exchange rate was 0.29 USD per $1 \mathrm{KWD}$ (in the range of USD 0.27 to USD 0.31 ). The observed average inflation rate was about $0.25 \%$ (within the range of $-0.83 \%$ and $2.2 \%$ ). Finally, we observed that the examined series were not normally distributed: Eq, Oil, and Int were left-skewed, while $M 2, E x$, and $C P I$ were right-skewed.

Table 2. Descriptive statistics

\begin{tabular}{lllllllll}
\hline Variable & Mean & Median & Min & Max & SD & Skewness & Kurtosis & N \\
\hline Eq & 6832.0 & 6444.6 & 1599.9 & 15456.2 & 2826.8 & 0.72 & 3.93 & 225 \\
Oil & 63.54 & 60.60 & 18.52 & 132.83 & 28.11 & 0.35 & 2.10 & 237 \\
Int & 0.0361 & 0.03 & 0.02 & 0.0725 & 0.0155 & 0.85 & 2.35 & 237 \\
M2 & 81412.1 & 87489.0 & 25205.1 & 128530.1 & 35798.9 & -0.25 & 1.49 & 236 \\
Ex & 0.29 & 0.29 & 0.27 & 0.31 & 0.01 & -0.49 & 2.30 & 237 \\
CPI & 89.83 & 90.64 & 64.97 & 116.3 & 18.22 & -0.03 & 1.46 & 237 \\
\hline gEq & 0.0057 & 0.0101 & -0.3237 & 0.1844 & 0.0573 & -1.2553 & 9.9881 & 224 \\
gOil & 0.0025 & 0.0174 & -0.3156 & 0.1851 & 0.0852 & -1.0147 & 4.5641 & 236 \\
gInt & -0.0041 & 0.0000 & -0.4274 & 0.2683 & 0.0505 & -3.1579 & 31.5848 & 236 \\
gM2 & 0.0067 & 0.0060 & -0.0483 & 0.0793 & 0.0177 & 0.7538 & 5.3086 & 235 \\
gEx & 0.0000 & 0.0000 & -0.0172 & 0.0321 & 0.0049 & 1.0792 & 12.6387 & 236 \\
gCPI & 0.0025 & 0.0014 & -0.0083 & 0.0220 & 0.0047 & 1.2436 & 5.5697 & 236 \\
\hline
\end{tabular}

The developments and distribution of the examined data are illustrated in Figures (1) and (2). We observed that the Kuwaiti index was increasing before the global financial crisis. Then, after the sharp decline, it stabilized in the 5000-6000 range. We also observed an appreciating national currency, which changed the direction of the trend after the financial crisis. Two periods of sharp decline were observed for oil prices: during the global financial crisis and at the end of 2015. The money supply and the CPI index illustrate steady growth. From Figure (1), we can confirm that the examined series are not normally distributed.
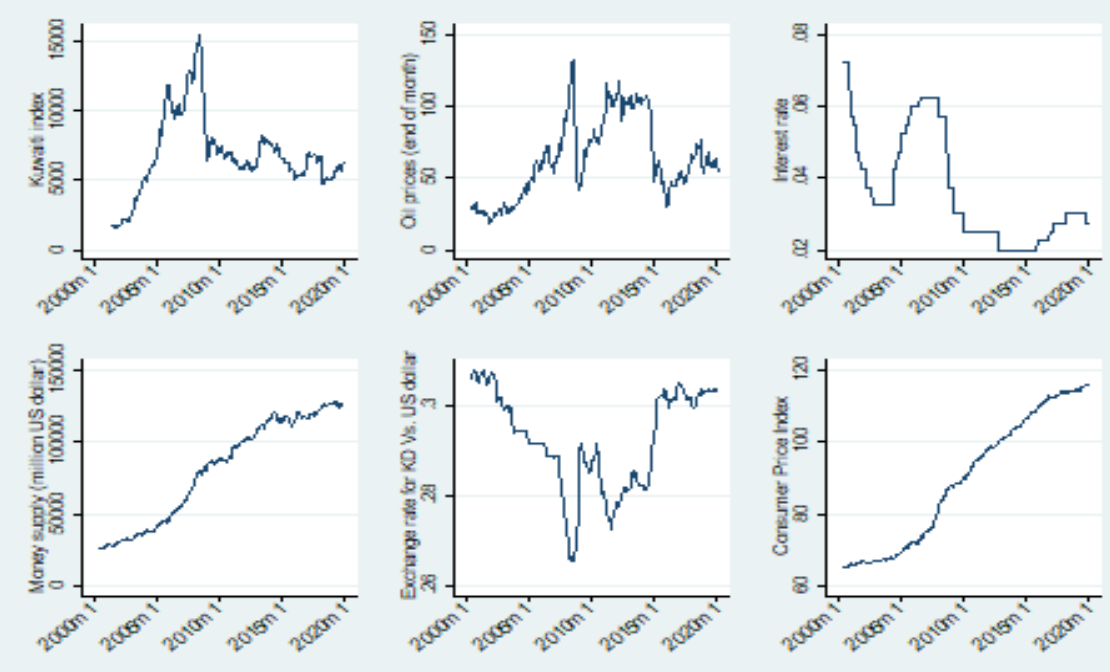

Figure 1. Main descriptive statistics by years-Trends 

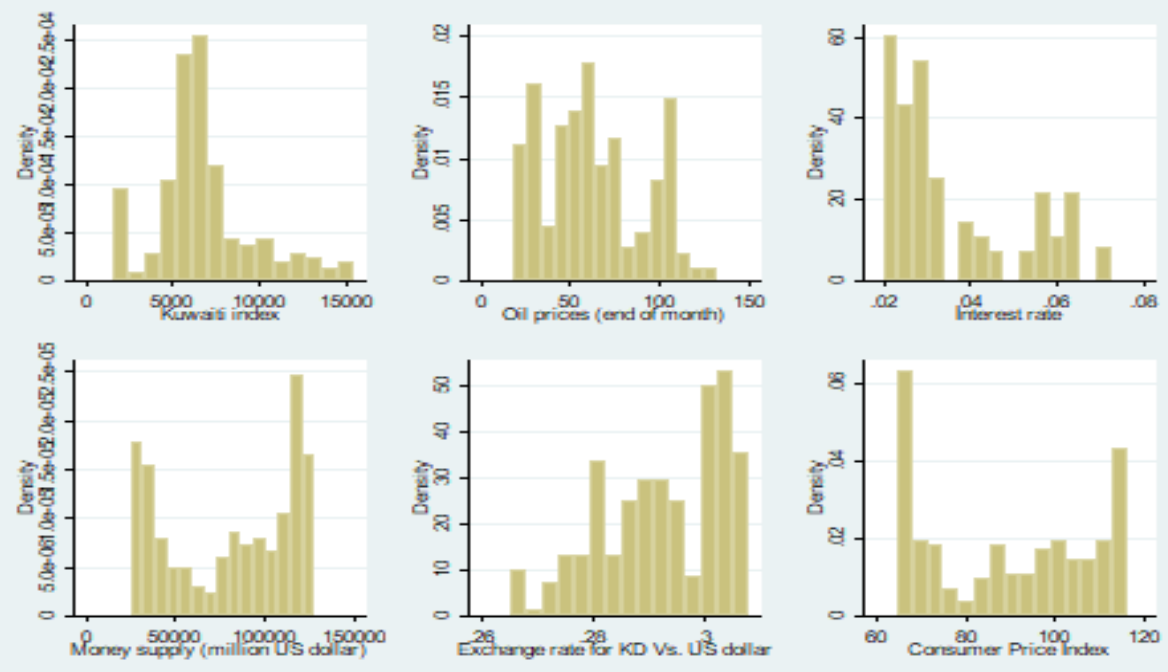

Figure 2. Main descriptive statistics by clustering

\section{Results}

This study provided estimates of the impact of oil prices on Kuwaiti stock market returns in the long-and short-term models. Table 3 summarizes the results of the ADF test for stationarity using the lag selection test.

Table 3. Lag selection criteria

\begin{tabular}{|c|c|c|c|c|}
\hline $\ln E q$ & Lag & $\mathbf{N}$ & AIC & BIC \\
\hline & 0 & 224 & -651.912 & -645.08902 \\
\hline & 1 & 223 & -673.342 & -663.12097 \\
\hline & 2 & 222 & -667.548 & -653.93746 \\
\hline & 3 & 221 & -671.764 & -654.77281 \\
\hline & 4 & 220 & -667.795 & -647.43279 \\
\hline \multirow[t]{6}{*}{ lnOil } & Lag & $\mathbf{N}$ & AIC & BIC \\
\hline & 0 & 236 & -492.785 & -485.85778 \\
\hline & 1 & 235 & -510.567 & -500.18843 \\
\hline & 2 & 234 & -505.686 & -491.86485 \\
\hline & 3 & 233 & -502.437 & -485.18225 \\
\hline & 4 & 232 & -498.146 & -477.46586 \\
\hline \multirow[t]{6}{*}{ Int } & Lag & $\mathbf{N}$ & AIC & BIC \\
\hline & 0 & 236 & -2227.98 & -2221.05 \\
\hline & 1 & 235 & -2215.75 & -2205.37 \\
\hline & 2 & 234 & -2203.54 & -2189.72 \\
\hline & 3 & 233 & -2197.52 & -2180.26 \\
\hline & 4 & 232 & -2185.28 & -2164.6 \\
\hline \multirow[t]{4}{*}{$\ln M 2$} & Lag & $\mathbf{N}$ & AIC & BIC \\
\hline & 0 & 235 & -1233.29 & -1226.3663 \\
\hline & 1 & 234 & -1225.62 & -1215.2527 \\
\hline & 2 & 233 & -1221.37 & -1207.5699 \\
\hline Publishe & & 5 & & 3-4023 E-ISSN 1923-4031 \\
\hline
\end{tabular}




\begin{tabular}{|c|c|c|c|c|}
\hline & 3 & 232 & -1215.4 & -1198.1676 \\
\hline & 4 & 231 & -1207.63 & -1186.9755 \\
\hline \multirow[t]{6}{*}{$\ln E x$} & Lag & $\mathbf{N}$ & AIC & BIC \\
\hline & 0 & 236 & -1834.9 & -1827.972 \\
\hline & 1 & 235 & -1900.2 & -1889.8194 \\
\hline & 2 & 234 & -1891.57 & -1877.7465 \\
\hline & 3 & 233 & -1880.6 & -1863.346 \\
\hline & 4 & 232 & -1869.68 & -1848.9983 \\
\hline \multirow[t]{6}{*}{$\ln C P I$} & Lag & $\mathbf{N}$ & AIC & BIC \\
\hline & 0 & 236 & -1858.04 & -1851.1159 \\
\hline & 1 & 235 & -1847.7 & -1837.3168 \\
\hline & 2 & 234 & -1837.38 & -1823.5573 \\
\hline & 3 & 233 & -1855.76 & -1838.5067 \\
\hline & 4 & 232 & -1845.45 & -1824.768 \\
\hline
\end{tabular}

Table 4 summarizes the results of the ADF test. According to the test, if we include deterministic trend, we fail to reject the null hypothesis of the existence of unit root, while the tests without the trend term indicate the stationarity of most of the variables. The tests for the first differences clearly indicate the stationarity of the examined series in the first difference. Thus, we consider the series as I(1) processes, which means they are stationary after the first difference only.

Table 4. Augmented Dickey-Fuller test for unit root

\begin{tabular}{lllllll}
\hline & \multicolumn{2}{c}{ Level, with trend } & \multicolumn{2}{c}{ Level, without trend } & \multicolumn{2}{c}{$\mathbf{1}^{\text {st }}$ difference } \\
\hline & Test stat & $\mathbf{P}$ & Test stat & $\mathbf{P}$ & Test stat & $\mathbf{P}$ \\
\hline $\ln E q$ & -2.3932 & 0.3832 & -2.7067 & 0.0037 & -10.3261 & 0.0000 \\
\hline $\ln O i l$ & -1.9889 & 0.6074 & -2.1412 & 0.0166 & -11.2263 & 0.0000 \\
\hline $\ln t$ & -1.7899 & 0.7096 & -2.3182 & 0.0107 & -15.384 & 0.0000 \\
\hline $\ln M 2$ & 0.1957 & 0.9958 & -2.8133 & 0.0027 & -15.3143 & 0.0000 \\
\hline $\ln E x$ & -1.8201 & 0.6950 & -1.8229 & 0.0348 & -8.5660 & 0.0000 \\
\hline $\ln C P I$ & -0.4245 & 0.9861 & -0.6298 & 0.2647 & -15.7001 & 0.0000 \\
\hline
\end{tabular}

According the cointegration test in Table 5, the corresponding lag order can be chosen based on different statistics, including AIC and BIC, as defined in the previous section. Following the most of the criteria, we choose 2 as the best lag order. The test results indicated the existence of cointegrated vectors. In other words, the stock market in Kuwait is highly exposed to the international oil market.

Table 5. Cointegration test results

\begin{tabular}{llllll}
\hline Maximum rank & $\mathbf{5 \%}$ trace parms. & Critical LL & eigenvalue & statistic & value \\
\hline 0 & 42 & 4062.866 &. & 158.2195 & 94.15 \\
1 & 53 & 4094.059 & 0.24498 & 95.8343 & 68.52 \\
2 & 62 & 4112.231 & 0.15102 & 59.4896 & 47.21 \\
3 & 69 & 4123.798 & 0.09896 & 36.3557 & 29.68 \\
4 & 74 & 4134.598 & 0.09271 & $14.7559 *$ & 15.41 \\
5 & 77 & 4141.047 & 0.05644 & 1.8594 & 3.76 \\
6 & 78 & 4141.976 & 0.00834 & & \\
\hline
\end{tabular}


In another investigation, because there was an existence of cointegration between the examined variables (suggesting that they do not follow stationary process, but their linear combination does), we utilized an ECM to estimate long-run and short-run interrelationships between the variables (Note 1). The results of the estimated panel error correction model are summarized in Table 6 .

Table 6. Error correction model

\begin{tabular}{|c|c|c|c|c|c|c|}
\hline \multicolumn{7}{|c|}{ Short term } \\
\hline & Coef. & Std. Err. & $\mathbf{z}$ & $\mathbf{P}>\mathbf{Z}$ & \multicolumn{2}{|c|}{ [95\% Conf. Interval] } \\
\hline$\alpha$ & -0.0340 & 0.0193 & -1.7700 & 0.0780 & -0.0720 & 0.0039 \\
\hline$\Delta \ln E q(t-1)$ & 0.3450 & 0.0662 & 5.2100 & 0.0000 & 0.2146 & 0.4754 \\
\hline$\Delta \operatorname{lnOil}(t-1)$ & 0.1371 & 0.0459 & 2.9800 & 0.0030 & 0.0465 & 0.2277 \\
\hline$\Delta \operatorname{Int}(t-1)$ & -2.2678 & 1.8823 & -1.2000 & 0.2300 & -5.9780 & 1.4424 \\
\hline$\Delta \ln M 2(t-1)$ & -0.0955 & 0.2101 & -0.4500 & 0.6500 & -0.5096 & 0.3186 \\
\hline$\Delta \ln E x(t-1)$ & 0.4679 & 0.7470 & 0.6300 & 0.5320 & -1.0044 & 1.9402 \\
\hline$\Delta \ln C P I(t-1)$ & 0.8799 & 0.7655 & 1.1500 & 0.2520 & -0.6290 & 2.3888 \\
\hline Cons & 0.0014 & 0.0043 & 0.3300 & 0.7400 & -0.0070 & 0.0098 \\
\hline \multicolumn{7}{|c|}{ Long term part } \\
\hline & Coef. & Std. Err. & $\mathbf{z}$ & $\mathbf{P}>\mathbf{z}$ & \multicolumn{2}{|c|}{ [95\% Conf. Interval] } \\
\hline $\operatorname{lnOil}(t-1)$ & 0.1013 & 0.0746 & 1.3600 & 0.1760 & -0.0459 & 0.2484 \\
\hline $\operatorname{Int}(t-1)$ & 17.1281 & 1.3841 & 12.3800 & 0.0000 & 14.4002 & 19.8560 \\
\hline $\ln M 2(t-1)$ & 2.8531 & 0.2331 & 12.2400 & 0.0000 & 2.3937 & 3.3125 \\
\hline $\ln E x(t-1)$ & 1.0548 & 0.8375 & 1.2600 & 0.2090 & -0.5958 & 2.7053 \\
\hline $\ln C P I(t-1)$ & -5.6816 & 0.5714 & -9.9400 & 0.0000 & -6.8079 & -4.5553 \\
\hline Cons & 2.4926 & 1.2523 & 1.9900 & 0.0480 & 0.0245 & 4.9608 \\
\hline
\end{tabular}

Number of obs. $=222$, RMSE $=.0522, \mathrm{R}-\mathrm{sq}=0.2084$, chi $2=56.36, \mathrm{P}>\operatorname{chi} 2=0.0000$

The findings showed that error correction coefficient $\alpha$ was statistically significant and negative. Thus, there is a long-run relationship between the examined variables, and any distortion of the equilibrium is adjusted by about $3.4 \%$ percent in each period. The findings also showed a statistically significant impact of the oil price variable on stock market returns. In the short run, the changes in the stock market index were affected only by the changes in oil price and its own lag. A $1 \%$ increase in oil price increased stock prices by about $0.14 \%$, and adaptively, the stock prices changed by about $34.5 \%$. Upon analysis of the other variables, the estimated coefficients of the exchange rate, money supply, and the inflation and interest rates had an insignificant impact on stock market returns. These insignificant findings of the control variables in the short run can be explained by the fact that the effect takes more than just a short period to be pronounced.

In the long run, stock prices were affected positively by the changes in interest rates and the money supply. A $1 \%$ increase in interest rates increased stock prices by about $17 \%$, while a $1 \%$ increase in M2 increased equity prices by about $2.9 \%$. Conversely, stock prices were negatively affected by CPI changes. A $1 \%$ increase in CPI decreased equity prices by about $5.9 \%$.

\section{Conclusion and Policy Implications}

This study investigated the impact of oil price fluctuations on the market returns of the Kuwaiti stock exchange during month-to month periods from 2000 to 2020. In order to study such correlation, the symmetric theory by Hamilton (1983) was used as a theoretical framework to include macroeconomic factors to investigate the determinants of stock market returns. In addition to using oil price as the independent variable, the estimated model also evaluated the following variables: interest rates, the inflation and exchange rates, and the money supply. 
The estimated model was examined using different approaches. The ADF test was used to evaluate the stationarity of the variables. The cointegration test was applied to specify the long-run relationship among the variables. And, finally, the ECM was used to determine the short-run relationship.

Our findings showed that there is a long-term relationship between oil prices and Kuwaiti stock market returns. This suggests that the capital market in Kuwait is highly exposed to external shocks. Thus, any drop in oil prices may lead to a dramatic drop in the general stock market index. In addition, the ECM examination showed that the oil price factor is also affecting stock market returns in the short run. Higher oil prices were expected to improve the stock market, while lower oil prices were responsible for eroding Kuwaiti stock market returns. This explained how the dynamics of a financial system work within a framework of a heavily oil-dependent economy.

There are some policy implications to be extracted from main results of this study. The Kuwaiti government needs to apply effective strategies to provide stability in its capital market. This can be accomplished by implementing solid policies to enhance the macroeconomic environment as well as allowing the market to have legal independence.

\section{References}

Ahmadi, M., Manera, M., \& Sadeghzadeh, M. (2016). Global oil market and the U.S. stock returns. Energy, 114, 1277-1287.

Akbar, S., Shah, S. Z., \& Saadi, I. (2008). Stock market reaction to capital expenditure announcements by UK firms. Applied Financial Economics, 18(8), 617-627. https://doi.org/10.1080/09603100701222234

Aldukhail, A. M. (2019). The effect of macroeconomic variables on the Saudi stock market. Archives of Business Research, 7(12), 126-152. https://doi.org/10.14738/abr.712.7508

Alenezi, M., Alqattan, A., \& Phiri, O. (2020). The sensitivity of GCC firms' stock returns to exchange rate, interest rate, and oil price volatility. Corporate Ownership \& Control, 17(4), 35-50.

Al-Fayoumi, N. A. (2009). Oil prices and stock market returns in oil importing countries: The case of Turkey, Tunisia and Jordan. European Journal of Economics, Finance and Administrative Sciences, 16(1), 84-98.

Almutairi, A., \& Alomar, H. (2007). Macroeconomic determinants of the behavior of Kuwait stock exchange. Studies in Business and Economics, 13(1), 39-50. https://doi.org/10.29117/sbe.2007.0029

Amarasinghe, A. A. M. D. (2015). Dynamic relationship between interest rate and stock price: Empirical evidence from Colombo Stock Exchange. International Journal of Business and Social Science, 6(4), 92-97.

An, Y., Sun, M., Gao, C., Han, D., \& Li, X. (2018). Analysis of the impact of crude oil price fluctuations on China's stock market in different periods-Based on time series network model. Physica A: Statistical Mechanics and Its Applications, 492, 1016-1031.

Antonkakis, N., \& Filis, G. (2013). Oil prices and stock market correlation: A time-varying approach. International Journal of Energy and Statistics, 1(1), 17-29.

Arouri, M. E. H., \& Nguyen, D. K. (2010). Oil prices, stock markets and portfolio investment: Evidence from sector analysis in Europe over the last decade. Energy Policy, 38(8), 4528-4539.

Arouri, M. E. H., Jouini, J., \& Nguyen, D. K. (2012). On the impacts of oil price fluctuations on European equity markets: Volatility spillover and hedging effectiveness. Energy Economics, 34(2), 611-617.

Burbidge, J., \& Harrison, A. (1984). Testing for the effects of oil-price rises using vector autoregressions. International Economic Review, 25(2), 459-484.

Burton, B. (2005). Concurrent capital expenditure and the stock market reaction to corporate alliance announcements. Applied Financial Economics, 15(10), 715-729. https://doi.org/10.1080/09603100500077060

Celebi, K., \& Hönig, M. (2019). The impact of macroeconomic factors on the German stock market: Evidence for the crisis, pre- and post-crisis periods. International Journal of Financial Studies, 7(2), 1-13.

Cheung, Y.-W., \& Lai, K. S. (1995). Lag order and critical values of the augmented Dickey-Fuller test. Journal of Business \& Economic Statistics, 13(3), 277-280.

Dickey, D., \& Fuller, W. (1979). Distribution of the estimators for autoregressive time series with a unit root. Journal of American Statistical Association, 74(366), 427-431.

Engle, R., \& Granger, C. (1987). Co-integration and error correction: representation, estimation, and testing. Econometrica, 55, 251-276. 
Fang, L., \& Bessler, D. A. (2017). Stock returns and interest rates in China: The prequential approach. Applied Economics, 49(53), 5412-5425.

Gisser, M., \& Goodwin, T. H. (1986). Crude oil and the macroeconomy: Tests of some popular notions: Note. Journal of Money, Credit and Banking, 18(1), 95-103.

González, M., Nave, J., \& Rubio, G. (2018). Macroeconomic determinants of stock market betas. Journal of Empirical Finance, 45, 26-44. https://doi.org/10.1016/j.jempfin.2017.10.003.

Green, S. L., \& Mork, K. A. (1991). Toward efficiency in the crude-oil market. Journal of Applied Econometrics, 6(1), 45-66.

Hamilton, J. D. (1983). Oil and the macroeconomy since World War II. Journal of Political Economy, 91(2), 228-248.

Jammazi, R. (2012). Cross dynamics of oil-stock interactions: A redundant wavelet analysis. Energy, 44, 750-777.

Kelikume, I., \& Muritala, O. (2019). The impact of changes in oil price on stock market: Evidence from Africa. International Journal of Management, Economics and Social Sciences (IJMESS), 8(3), 169-194.

King, B. F. (1966). Market and industry factors in stock price behavior. The Journal of Business, 39(1), 139-190.

Lin, C. C., Fang, C. R., \& Cheng, H. P. (2010). Relationships between oil price shocks and stock market: an empirical analysis from Greater China. China Economic Journal, 3(3), 241-254.

Mensi, W., Aloui, C., Hamdi, M., \& Nguyen, D. K. (2012). Crude oil market efficiency: An empirical investigation via the Shannon entropy. International Economics/Economie internationale, 1(128), 119-137.

Pícha, V. (2017). Effect of money supply on the stock market. Acta Universitatis Agriculturae et Silviculturae Mendelianae Brunensis, 65(2), 465-472.

Sahin, A. (2014). Stock market returns and oil prices relationship revisited. In Quo Vadis Social Sciences: Artvin Coruh University International Congress on Social Sciences, Artvin, Turkey, October (pp. 15-17).

Soumaré, I., \& Tchana, F. T. (2015). Causality between FDI and financial market development: Evidence from emerging markets. The World Bank Economic Review, 29(Suppl 1), 205-216. https://doi.org/10.1093/wber/lhv015

\section{Note}

Note 1. Because we are interested in explaining only the Kuwait index, we used an ECM, rather than a VECM.

\section{Copyrights}

Copyright for this article is retained by the author(s), with first publication rights granted to the journal.

This is an open-access article distributed under the terms and conditions of the Creative Commons Attribution license (http://creativecommons.org/licenses/by/4.0/). 